\begin{tabular}{|c|c|c|c|}
\hline Article Info & RESEARCH ARTICLE & ARAŞTIRMA MAKALESİ & \\
\hline Title of Article & \multicolumn{2}{|c|}{$\begin{array}{c}\text { The Importance of Using Photovoltaic } \\
\text { Panels (PV) in Buildings in the Corporate } \\
\text { Environmental Responsibility of Local } \\
\text { Governments }\end{array}$} & \\
\hline $\begin{array}{l}\text { Corresponding } \\
\text { Author }\end{array}$ & \multicolumn{2}{|c|}{$\begin{array}{l}\text { Setenay UÇAR } \\
\text { Antalya Bilim Üniversitesi, Güzel Sanatlar ve Mimarlık Fakültesi, İç Mimarlık ve Çevre } \\
\text { Tasarımı Bölümü, setenay.ucar@antalya.edu.tr }\end{array}$} & \\
\hline $\begin{array}{l}\text { Received Date } \\
\text { Accepted Date }\end{array}$ & \multicolumn{2}{|l|}{$\begin{array}{l}31 / 05 / 2020 \\
20 / 10 / 2020\end{array}$} & \\
\hline Author / Authors & $\begin{array}{l}\text { Öğr. Gör. Setenay UÇAR } \\
\text { Doç Dr. İlknur AKINER }\end{array}$ & $\begin{array}{l}\text { ORCID: 0000-0003-4206-6094 } \\
\text { ORCID: 0000-0002-9550-146X }\end{array}$ & \\
\hline How to Cite & \multicolumn{2}{|c|}{$\begin{array}{l}\text { Uçar, S. ve Akıner, İ. (2020). Yerel Yönetimlerin Kurumsal Çevre Sorumluluğunda } \\
\text { Binalarda Fotovoltaik Panel (PV) Kullanımlarının Önemi, Kent Akademisi, Volume, } 13 \\
\text { Issue 4, Pages, 584-598 }\end{array}$} & $\begin{array}{l}\text { Kent Akademisi } \\
\text { Urban Academy }\end{array}$ \\
\hline
\end{tabular}

\title{
Yerel Yönetimlerin Kurumsal Çevre Sorumluluğunda Binalarda Fotovoltaik (PV) Panel Kullanımlarının Önemi
}

Öğr. Gör. Setenay UÇAR ${ }^{1}$

Doç Dr. İlknur AKINER ${ }^{2}$

\begin{abstract}
:
Corporate social responsibility is composed of strategic goals for institutions that will stand out in a competitive environment and strengthen their corporate image. Corporate environmental responsibility, which is the subtitle, requires the organization to determine strategies that are environmentally conscious and to be sensitive to the life and living environment by reducing carbon emissions. As most energy consumption is in the buildings, the most important environmental steps of the institutions are to save energy in their buildings. With this study, the use of PV panels with solar and PV panels, which are among the alternative renewable energies, will be examined. As the corporate environmental responsibility develops in local government buildings every year, the effect of PV panels on the building form and the energy savings they provide will be analyzed within the scope of this study. The PV panels, which can be integrated into the existing building design and newly built buildings according to the form of the buildings, are evaluated over the climate, region, solar radiation and the total area covered on the building.
\end{abstract}

KEYWORDS: Corporate Environmental Responsibility, Renewable Energy, Sustainability, Photovoltaic Panels, Architecture and Environment

\section{ÖZ:}

Kurumsal sosyal sorumluluk kurumlar için, rekabet ortamında kendisini ön plana çıkaracak ve kurumsal imajını güçlendirecek stratejik hedeflerden oluşmaktadır. Kurumsal çevre sorumluluğu ise, kurumun çevre bilincine uygun stratejiler belirlemesi, karbon salımının azaltılması ile canlıların yaşamına ve doğal çevreye karşı duyarlı olması gerekmektedir. En fazla enerji tüketiminin binalarda olması nedeniyle kurumların en önemli çevre adımları binalarındaki enerji tasarrufunu sağlamak olmalıdır. Bu çalışmada, binalarda tüketilen enerji ve bu ihtiyacı karşılamak için kullanılan alternatif yenilenebilir enerji kaynaklarından biri olan güneş enerjisi (PV paneller) ele alınmaktadır. Kurumsal çevre

\footnotetext{
${ }^{1}$ Antalya Bilim University, Faculty of Fine Arts and Architecture, Interior Architecture and Environmental Design, setenay.ucar@antalya.edu.tr

${ }^{2}$ Akdeniz University, Faculty of Architecture, Architecture, ilknurakiner@gmail.com
} 
sorumluluğunun yerel yönetim binalarında her sene geliştirmesi nedeniyle bu çalışma kapsamında 4 yurtiçi ve 4 yurtdışı olmak üzere toplam 8 yerel yönetim binası PV panellerin bina formu üzerinde etkisi ve sağladıkları enerji tasarrufu incelenecektir. Binaların formuna göre mevcut binaya sonradan eklenen ve yeni yapılan binalara tasarım aşamasında entegre olabilen PV panellerin iklim, bölge, güneş 1şınımları ve bina üzerinde toplam kaplanan alan üzerinden değerlendirilmesi yapılmaktadır.

ANAHTAR KELIMELER: Kurumsal Çevre Sorumluluğu, Yenilenebilir Enerji, Sürdürülebilirlik, Fotovoltaik (PV) Paneller, Mimarlık ve Çevre

\section{"Yerel Yönetimlerin Kurumsal Çevre Sorumluluğunda Binalarda Fotovoltaik Panel (PV) Kullanımlarının Önemi”}

\section{GíRiş}

Dünya üzerinde en fazla enerji ihtiyacı inşaat sektöründe gerçekleşmektedir (Sağlam ve Yılmaz, 2015; Directive 2010/31/EU, 2010). Özellikle bina yapım süreci boyunca önemli miktarda enerji harcanmaktadır. Bu nedenle binaların üretim aşamasında enerji tüketim miktarının en aza indirilmesi, fosil yakıt tüketim miktarının azaltılması açısından oldukça önemlidir. Binalar sadece üretim aşamasında değil, aynı zamanda yaşamları boyunca tüketilen enerji miktarını azaltmak için yaşam döngüsü boyunca da incelenmelidir (Arslan ve Akşit, 2016). Aynı zamanda binaların inşaat öncesi aşamadan başlayarak, geri dönüşüm aşamasına kadar süren yaşam döngüsünde de karbondioksit salımının üçte biri binalar tarafından gerçekleştirilmektedir.

Günümüzde nüfusun artması ve teknolojinin gelişmesiyle enerji ihtiyacı her geçen gün artmaktadır. Azalan kaynaklar ve artan enerji ihtiyacı, yenilenebilir enerjilere yönelimleri arttırmaktadır. Güneş enerjisi, rüzgar enerjisi ve biyokütle enerjisi en fazla kullanılan yenilenebilir enerji kaynaklarındandır. Ancak güneş enerjisinin kullanımı en düşük güneşli gün sayısına sahip ülkelerde bile oldukça verimli kullanılmasını sağlamaktadır. Araştırmalara göre, 2040 yılından itibaren güneş enerjisi en az düzeyde karbon enerjisi üretimini sağlayacak ve 2040'a kadar toplam elektrik üretiminde yenilenebilir enerjinin kullanımının \%40'a ulaşacağını göstermektedir (URL1). Binalarda enerji tüketimi, 2009 yılında Avusturya Viyana'da yapılan sıfır enerjili bina yapımı ile sıfır enerji hedeflenmiştir Aynı zamanda bu kapsamda, Amerika'da sıfır enerjili binaları artırmayı hedefleyen programlar yürütülmektedir. Sıfır enerjili binalar ile 1sı yalıtımının yapılması, pencerelerde güneş kontrol kaplamalı camlar, 1sı pompası kullanılması, binanın sıcak su ihtiyacını karşılamak için kolektörler ve elektrik tüketimi için ise fotovoltaik panellerin kullanılması hedeflenmektedir. Bu hedefler arasında kurumsal çevre sorumluluğunun kapsamı, kağıtların geri dönüşümlü olmasından, çevre kullanımlarını arttırılması, enerji tüketiminin azaltılması, havada, suda ve karada zehirli kirleticilerin engellenmesi veya bina enerji verimliliği konularına kadar geniş bir alan kapsamaktadır. AB'de, Binalarda Enerji Performansı Direktifi (EPBD)'ne göre, EPBD ile binalar için “optimum maliyet seviyesi” ve "yaklaşık sıfır enerji bina" kavramları tanımlanmıştır (Sağlam ve Yılmaz, 2015). Bu da en az maliyetle en fazla enerji verimliliği sağlayan ülkelere göre değişen tedbirler olarak belirlenebilmektedir. Böylece her ülkenin kendi koşullarına göre yaklaşık sıfır enerji seviyelerini belirlemesi ve bunu uygulaması beklenmektedir. Bunun nedeni de iklimlerin, coğrafi konumların ve topografyanın farklı olmasından kaynaklanmaktadır. Türkiye'de, binalarda enerji verimliliğinin sağlanmasına yönelik mevzuat, $\mathrm{AB}$ mevzuatı uyum süreci dikkate alınarak düzenlenmiş. 2008'de yayımlanan, 2010'da revize edilen Binalarda Enerji Performansı Yönetmeliği uyarınca, ulusal bina enerji kimlik belgesi uygulaması getirilmiş. Ardından, 2023 yılına kadar, tüketilen enerjinin 2011'e kıyasla en az \%20 oranında azaltılması hedefi koyulmuştur (URL 10).

Yerel yönetim binaları en fazla enerji tüketemi olan binalardır. Sadece İstanbul Büyükşehir Belediyesi’nin elektrik tüketimi tüm Türkiye'nin kullandığı elektrik tüketiminden \%1’i kapsamaktadır (İSKİ, 2018). Bu çalışma ile yerel yönetim binaları ele alınmış ve elektrik tüketimi en fazla alan binalara yönlenmesi gerektiği açıklanmıştır. Ayrıca bu konuda farkındalık yaratarak gelecek inşaat projeleri için yenilenebilir enerji kaynaklarının binalara entegre edilmelerinin hem estetik hem de çevreye zararlı emisyonları engellemek açısından önemi incelenecektir. Bu inceleme kurumsal çevre sorumluluğun, yerel yönetimler için her sene stratejik hedef oluşturmaları ve bu hedefler doğrultusunda binalarına sonradan da entegre edilebilecek fotovoltaik panellerin uygulamalarına yönelik yurtiçi ve yurtdışı örnekleri kapsamaktadır.

\section{Kurumsal Çevre Sorumluluğu}

Sorumluluk kavramı Türk Dil Kurumu (TDK) tarafından "kişinin kendi davranışlarının veya kendi yetki alanına giren herhangi bir olayın sonuçlarını üstlenmesi" olarak tanımlanmaktadır (URL2). Sosyal sorumluluk kavramı olarak sadece 
bireylerin değil, aynı zamanda toplumsal bir alanı kapsamakta olan sorumluluk olarak tanımlanmaktadır. Bu nedenle hem bireylerin hem de kurumların topluma karşı sorumluluklarının olması doğal olarak kurumsal sosyal sorumluluk (KSS) kavramını oluşturmuştur. Stratejik yönetimin olması kapsamında sosyal sorumluluk kavramına göre "Şirketler, onlara kar olanakları sağlayan bir toplumun içinde faaliyet gösterirler. Bunun karşılığında, toplumsal gereksinimlere hizmet etmek gibi bir zorunlulukları vardır. Bu zorunluluğa sosyal sorumluluk denir" şeklinde özetlemektedir (Akkoyunlu ve Kalyoncuoğlu, 2014). Kurumsal sosyal sorumluluk kavramı 1950'li yıllarda ilk olarak Bowen (1953) tarafından; kurumların, toplumun hedef ve değerlerine paralel şekilde kararlar alması ve buna uygun politikaları takip etme zorunluluğu olarak tanımlamıştır. Türkçe olarak literatüre ilk defa 2005 yılında adı "Kurumsal Sosyal Sorumluluk" isimli kitapta yer alan "kurumsal sosyal girişimler" kavramı olarak adlandırılmış ve "sosyal amaçları desteklemek ve kurumsal sosyal sorumluluk yükümlülüklerini tamamlamak için bir kurum tarafından üstlenilmiş büyük çaplı faaliyetler" olarak değerlendirilmiştir (Mert, 2018).

Kurumsal sosyal sorumluluk kavramının amacı, paydaşların, çalışanların, işverenlerin, müşterilerin ve tedarikçilerin beklentilerini yasal olmak koşuluyla gerçekleştirilen tüm faaliyetlerde beklentilerini karşılamaktır. Kurumsal sosyal sorumluluk genel tanımı ise, işletmenin gerçekleştirdiği bu faaliyetlerin gönüllük ilkesine bağlı olduğunu belirtmektir. Türkiye'deki sivil toplum tarih olarak hem uzun bir geçmişe sahip hem de kısa bir zaman dilimini kapsamaktadır. Kurumsal sosyal sorumluluk çalışmaları ilk olarak Osmanlı Devleti zamanında Osmanlı vakıf kültürü olarak görülmekteydi. Osmanlı Devleti'nde kent kurabilmek için sosyal ve kültürel olarak gereklilikleri yerine getiren vakıf, İslamiyet'inde getirdiği hayırseverlik faaliyetleri ile birleşince Osmanlı Devleti'nde varlıklı aile üyelerinin gönüllü olarak mal ve mülk bırakmasına bu şekilde yardımcı olmuştur. Daha sonra 1980'lerde başlayan Batılılaşma çabası olarak nitelendirilen dönemle birlikte Cumhuriyet Dönemi'nde sosyal refahı sağlayan kurum devlet olarak kabul edilmiş ve vakıflar kaldırılmıştır. Yeniden vakıf sistemine dönülmese bile sosyal sorumluluklara dair çalışmaların başlaması 1980'lerden sonra ekonomik özgürlük ile iş dünyasında başlamıştır. Ancak Türkiye'deki şirketler sosyal sorumluluk kavramını sponsorluk olarak veya halkla ilişkiler faaliyeti olarak görmektedir. Kurumlar sosyal adalet konularındaki çalışmalar yerine eğitim, çevre, kültür, spor gibi alanlarda kurumsal sosyal sorumluluk çalışmaları faaliyet göstermektedir. Toplumun iş dünyasından eğitim, sağlık, çevre ve aile içi şiddet konularında sorumluluk çalışmaları sürmekte ve farkındalık yaratarak çözümler aranmaya devam etmektedir. Böylece, Türkiye için şirket ve kurumların kurumsal sosyal sorumluluk faaliyetleri olarak topluma bakış açılarını yansıtmakta ve farklı işbirlikleri ile farklılıklarını topluma göstermektedir. Gelişmiş ülkelerde daha hızlı gelişen ve önemli bir kavram olan kurumsal sosyal sorumluluk Türkiye'de geçmişe dayanan bir tarihi olmasına rağmen günümüzde yeni olarak faaliyetlere büyük firmalar tarafından gelişmeye devam etmektedir. Orta ölçekli işletmelerinde ise kurumsal sosyal sorumluluk şirketlerinin politikaları olarak günümüzde çok az faaliyet gösterdikleri görülmektedir.

İşletmelerin çevreye karşı sorumlulukları da günümüzde küresel ısınmanın artması ve ekolojik dengenin bozulmasıyla daha da önemli bir alan haline gelmiştir. Özellikle 1950'lilerde başlayan sanayileşme ile birlikte teknolojinin her alanda artması, üretim esnasında çevreye yayılan zehirli gazların artmasına, zararlı kimyasal atıklar oluşmasına, su ve havayı kirleterek ekosisteme zarar vermeye neden olmaktadır. Bu nedenle çevreye zarar verecek her türlü zararlı etmeni azaltmak için üretim esnasında tedbirler almalıdırlar. Bu gereklilikleri yerine getiren kurumların toplum tarafından daha olumlu karşılanmakta ve sosyal bir varlık olma özelliğini sağlayarak önemli hedefleri yerine getirmektedirler (Pelit ve diğerleri, 2009). Çevre korumanın yanı sıra şirketler için önemli katkıları da olmaktadır. Bu katkılar Mert (2018)’e göre, işletmenin finansal performansının olumlu olarak artış göstermesi, atıkların azaltılması ve enerji tasarrufunun sağlanmasıyla enerji maliyetlerinin azaltılması, kullanılan malzemelerin geri dönüşümle birlikte yeniden üretim ile yeni ürünler olarak kullanılması bunlardan birkaçıdır. Bu sayede işletme saygınlığının arttırılmasını sağlamak ve marka imajının artmasını görmek mümkündür (Mert, 2018).

KSS alt birimi olan Kurumsal Çevre Sorumluluğu (CER / KÇS) Türkiye’de yeni bir kavramdır. Özellikle belediye, sanayi kuruluşları, işletmeler ve özel sektörler için paydaşlar ile olan ilişkilerinde kar amacı gütmeden gönüllülük üzerine kullanılan kavramdır. Çevreye salınan zararlı gazlar, karbondioksit emisyonları, ekolojik dengeyi bozacak her türlü kullanımın önüne geçmeyi hedeflemiştir. Yenilenebilir enerjilerin kullanılması ile çevreye duyarlı olan kurumların yenilenebilir enerji kaynaklarını kullanabilmesi güneş, rüzgar, biyokütle gibi birçok enerji çeşidi ile mümkündür. Tüm enerjiler içerisinde en fazla elektrik üretimi güneş enerjisi potansiyeli ile sağlanmaktadır. Özellikle 2020 yılından sonra yapılacak tüm binaların yaklaşık sıfır enerji (YSE) bina olması zorunluluğu getirilmesinden dolayı tüm binalarda yenilenebilir enerjilere yer verilmesi gerekmektedir. Yeni yapılacak olan binalar dışında mevcut binalara da entegre edilebilen sistemler kurulmalıdir.

EPBD'nin 2018'deki son revizyonunda, mevcut binaların iyileştirilmesi hususuna daha fazla vurgu yapılarak, uzun dönem iyileştirme stratejilerinin, ulusal ölçekte gelecek hedefleriyle uyum içinde geliştirilmesi gerektiği belirtilmiş. 
Yenilenebilir enerjilerin kullanılması ile çevreye duyarlı olan kurumların özellikle elektrik ihtiyacını karşılayabilmek için fotovoltaik panellere (PV) yönelimler artmaktadır.

\section{Fotovoltaik Panel Kullanımının Etkileri}

Artan enerji ihtiyacı ve tükenen fosil yakıtların yok olmasına engel olmak için güneşe yönelmek hem finansal açıdan hem de çevreyi korumak açısından önemli bir avantajdır. Yenilenebilir enerji kaynaklarından olan güneş enerjisinin temiz enerji olarak hem çevresel hem de sağlık açısından faydaları bulunmaktadır.

\subsection{Hava Kirliliğini Önlemesi}

Her yıl, enerji sektörü atmosfere tonlarca gaz yayar ve bunların büyük bir kısmı kükürt dioksit, azot oksit ve partikül madde gibi önemli hava kirleticileridir. Bu emisyonların çoğu, fosil yakıtlardan elektrik üretmek için kullanıldığında meydana gelmektedir. Havadaki kirletici olan bu maddeler her yıl düzenli olarak artmaktadır. Uluslararası Enerji Ajansına (IEA) göre 2015 yılında Çin ve Amerika aşırı azot ve kükürt birikiminden dolayı ekosistemi etkileyen en büyük iki ülkedir. Sonuçlara göre emisyonların üçte birini bu ülkeler oluşturmaktadır ve ekosisteme büyük zarar vermektedirler.

Hava kirliliğinin ekosistemler üzerindeki olumsuz etkilerinden bazıları şunlardır:

- Biyoçeşitliliğin azalması

- Daha düşük ürün veriminin artması

- Asit yağmuru nedeniyle ormanların olumsuz etkilenmesi

- Su kaynaklarının kalitesinin bozulması

Hava kirliliği, yeryüzündeki tüm canlı organizmalara bir şekilde zarar vermektedir. Bu durumda teknolojik gelişmelerin iyileştirilmesi sayesinde, enerji ihtiyacı yenilenebilir enerji kaynaklarından karşılanabilir. Güneş enerjisinde gelişen teknolojinin yardımıyla zararlı emisyonları azaltarak çevresel ayak izinin koruması hedeflenmiştir. Fotovoltaik panellerinin kullanımları toplam enerji üretiminde güneş enerjisinin payını artırarak, yüksek miktarlarda hava kirleticileri önlenebilir. Bu etki için, Amerika'da $100 \mathrm{GW} l$ 'lk bir güneş enerjisi kapasitesinin eklenmesi, her yıl en az 70.000 ton azot oksit ve 126.000 ton sülfür dioksit emisyonunun önlenebileceği tahmin edilmektedir (Grover, 2007). Böylece ekosistemlerin çeşitliliğine büyük ölçüde fayda sağlayacaktır.

ABD Çevre Koruma Ajansı (EPA), elektrik üretiminin ABD'de en büyük endüstriyel hava emisyonu kaynağı olduğunu bildirmektedir. Fosil yakıtla çalışan santraller, insan yapımı karbondioksit $(\mathrm{CO} 2)$ emisyonlarının \%40'ından, ülkenin azot oksit (NOX) emisyonlarının \%23'ünden ve kükürt dioksit (SO2) emisyonlarının \%67'sinden sorumludur. Bu emisyonlar çok çeşitli sağlık problemleri ile ilişkilidir. Ayrıca, fosil yakıtla çalışan enerji santralleri tarafından yayılan sera gazı (örn., Karbondioksit), iklim değişikliği riskini artırmaktadır.

\section{2 İklim değişikliğini azaltmaya yardımcı olması}

Fotovoltaik paneller ile güneş enerjisinden elektrik sağlamanın sonucunda sera gazı açığa çıkmaz ancak fotovoltaik panellerinin üretimi ve kurulumu sırasında bazı sera gazları açığa çıkar. Bu miktar, standart bir kömür yakıtlı enerji santralinin emisyonlarından on kat daha azdır (WNA Report, 2019).

Atmosferde doğal olarak karbon dioksit bulunmasına rağmen, enerji ihtiyacı sanayi devriminden bu yana doğal olan seviyeyi değiştiriyor. Bu durum, dünyada küresel ssınma gibi sonuçların kaçınılmaz olduğu anlamına gelmektedir. Güneş enerjisi, enerji sektörünün iklim değişikliği üzerindeki etkisini hafifletmek için büyük bir potansiyele sahiptir. Ulusal Yenilenebilir Enerji Laboratuvarı (NREL) tarafından yapılan bir araştırma, kömür santrallerinin 100 GW güneş enerjisi ile değiştirilmesinin her yıl 100 milyon tondan fazla karbondioksit emisyonunu ortadan 
kaldırabileceğini göstermektedir (Grover, 2007). 2016 yılı verilerine göre Amerika'da faaliyet gösteren $20 \mathrm{GW}$ güneş enerjisi tesisi yılda 17 milyon ton sera gazı emisyonunu dengelemektedir (URL 3).

Hu ve diğerlerine (2015) göre, bir şehirde fotovoltaik panellerin kullanılması o çevre üzerinde iki dereceye kadar soğutma etkisi göstermektedir. Bunun sebebi, fotovoltaik panelleri olan binaların güneş enerjisini yakalayıp elektriğe dönüştürmesi, fotovoltaik panelleri olmayan binaların ise güneşten gelen radyasyonun bir kısmını soğurarak ısıya dönüştürmesidir. $\mathrm{Bu}$ gözlemlere göre, çatılarda, cephelerde, gölgeleme elemanlarında, yollarda veya kaldırımlarda kullanılan fotovoltaik panelleri, şehir ısı adası etkisini yaz sıcağı dalgaları boyunca minimumda tutarak şehir iklimlerini etkileyebilir (Hu ve diğerleri, 2015).

\subsection{Su kirliliğinin önlenmesi}

Enerji santrallerinin çoğunda, türbinler için buhar üretmek ve daha sonra sistemi soğutmak için büyük miktarlarda suya ihtiyaç vardır. fotovoltaik hücrelerinin elektrik üretmek için suya ihtiyacı yoktur. Kaynak sularının az olduğu ve her sene dünya genelinde ciddi kuraklık sorunlarıyla mücadele edildiği göz önüne alındığında, fotovoltaik panellerin kullanımları en önemli çevresel faydalarından biri olmaktadır.

Su kirliliğinin \%72'sini oluşturan kömür santrallerinin yerini fotovoltaik panellerin almasıyla su kaynaklarını korumak ve temiz içme suyu kaynaklarının tükenmesini önlemek amaçlanmıştır. Madencilik sektöründe, özellikle de kömür için, su kalitesinin bozulmasında önemli bir rol oynamaktadır. Madencilik genellikle kayaların ağır metal içeriğini sülfürlü mineraller ile açığa çıkarmaktadır. Yağmur suyu bunlarla reaksiyona girdiğinde, onları topraklara, göllere ve nehirlere taşır. Ekosistemler ve tarım arazileri ile birlikte bitkiler, hayvanlar ve hatta insanlar için zehirli hale gelirler. Enerji santrallerinden kullanılan suyun tekrar doğal su kaynaklarına dönüştürülebilmesi de ek bir kirlilik oluşturmaktadır. Bu oluşan su normalden fazla sıcak olmasından dolayı suda yaşayan canlıların yaşamlarını sürdüremediği veya olumsuz etkilenmesine sebep olmaktadır.

Fotovoltaik panellerin üretim süreci ve bakımları içinde biraz su gerektirmektedir, ancak bu ihtiyaç bir örnekle kıyaslanacak olursa; bir kömür santrali, bir güneş sisteme kıyasla bir megavat-saat elektrik üretmek için 3.500 kat daha fazla suya ihtiyaç duyuyor. Benzer şekilde, bir nükleer santral, 1.500 kat daha fazla su gerektirir (URL4). Güneş enerjisi çiftlikleri bu nedenle yerel su kaynaklarını bozulmamış ve kirlilikten arındırılmışır.

\subsection{Kaynak Kullanımını Azaltması}

Güneş enerjisi üretimi ve kullanımı bakımından daha az kaynak gerektirmektedir. Kömür elektriğine kıyasla, güneş enerjisi aşağıdaki etkileri sağlamaktadır:

- $\quad$ Suyu sadece \%11-14 tüketmesi,

- Arazinin \%20'sini kullanmas1,

- $\% 95$ daha az toksik madde bulundurmas1,

- Asit yağmuru şansını \%92'den \%97'ye düşürmesi en önemli etkilerdendir (URL 4).

Güneş teknolojisi, çıkarılması ve işlenmesi gereken kaynaklardan oluşmasına rağmen, silikon fotovoltaik panellerde bulunan malzemenin \%96'sı geri dönüştürülebilir. Bu malzemeler, alüminyum, gümüş, galyum, indiyum ve germanyum gibi nadir veya değerli metaller gibi önemli kaynakları içermektedir. Fotovoltaik paneller güneş pillerindeki (silikon ve kadmiyum tellürid) ana malzemelerin \%90'ına kadarı, yeni güneş pilleri üretmek için yeniden kullanılabilmektedir. Böylece, fosil yakıtların sadece bir kez kullanılabildiğinden güneş enerjisini fosil yakıtlara kıyasla çok daha çevre dostu yapar. Örneğin, petrol şirketleri petrolün 24 saat, haftada yedi gün, yılda birkaç yıl içinde 365 gün ayıklayabilmesine rağmen, bir kez çıkarılıp kullanıldığında, bu tükenen kaynağın yeniden kullanılmasının bir yolu yoktur. Öte yandan fotovoltaik paneller 20 yılı aşkın bir süredir enerji üretmeye devam ediyor ve geri dönüştürülerek yeni formda bir kez daha enerji üretmeye devam etmesi sağlanıyor.

\section{5 Çevre Kirliliğini Önlemesi}

Canlıların yaşamları ve ekosistemin bozulması fosil yakıtlara olan bağımlılıktan kaynaklanan kirlilikten etkilenir. Petrol sızıntıları, madenlerden asit drenajı, santraller nedeniyle zehirli sular, ormanların tahrip edilmesi, suda yaşayan 
organizmaların ölümleri bunlardan birkaçıdır. Dünyada fosil yakıt kirliliği nedeniyle kaç kişinin sağlık problemi yaşadığını söylemek zordur, ancak sorunun ölçeği o kadar büyüktür ki yetersiz beslenme gibi diğer önemli sağlık risk faktörlerini aşmaktadır. Fosil yakıtların kullanımı güneş enerjisi kullanımı ile değiştirilmesi, yaşamak, yemek yemek için ihtiyaç duyulan çevrenin güvenliğini artırabilir. Güneş enerjisi ile fotovoltaik panel kullanımı ile mevcut çevredeki ekosisteme olumsuz etkisi, herhangi bir fosil yakıttın etkisinden çok daha düşüktür.

\section{Yerel Yönetimlerin Kurumsal Çevre Sorumluluğuna Dair Çalışmalar}

Hükümetlerarası İklim Değişikliği Paneli'nin 2014 yılında hazırlanan raporuna göre, enerji kullanımına bağlı CO2 emisyonlarının \%71-76'sının; küresel enerji tüketiminin ise \%67-76'sının şehirlerde gerçekleştiğini ortaya koymuştur. Uluslararası Yenilenebilir Ajansı'nın 2016 yılında yayınlanan raporuna göre ise 2030 yılına gelindiğinde, şehirlerdeki enerji ihtiyacının, \%35 artacağı öngörülmektedir (URL6). 2018 yılındaki verilere göre dünya nüfusunun \%55'i şehirlerden oluşmaktadır ve bu rakam 2050 yılında bu oranın \%68'e ulaşması beklenmektedir (URL5). Günümüzde artan enerji ihtiyacı ve nüfusunda artmasıyla beraber iklim değişikliği şehirlerdeki yaşamı ve olumsuz olarak etkilemektedir. Bu nedenle şehirlerde enerji ihtiyacının karşılanması ve iklim değişikliğinin olumsuz etkilerinin azaltılmasına yönelik yerel düzeyde alınan kararlar ve önlemler de günden güne önem kazanmaktadır (Van Staden, 2017). Enerji kullanımının yoğunlaştığ 1 şehirlerde, iklim değişikliği ile mücadele politikaları eşliğinde alınacak kararlar, ulusal ve küresel düzeyde iklim değişikliği ile mücadele ve adaptasyon için gerekli görülmektedir (Van Staden, 2017).

Yerel yönetimler kapsamında belediyeler, kamu yönetiminde önemli bir alanı oluşturmaktadır. Örnek olarak, Türkiye'de İstanbul Büyükşehir Belediyesi (IBB)'ne bakılacak olursa; 2018 yılındaki verilere göre artan enerji maliyetlerini düşürmek aynı zamanda mevcut yenilenebilir enerjiyi en verimli şekilde kullanmak amacıyla belediyenin sorumluluğundaki binalarda çalışmalar yürütülmektedir. Ayrıca İBB’ye (2018) göre, Binalarda Enerji Performansı Yönetmeliği'nin 4. Maddesinin birinci fikrası gereğince tüm binalarda istenilen Enerji Kimlik Belgesi zorunluluğu yerine getirilmiş olup, bu çalışma ile İstanbul Büyükşsehir Belediyesi binalarının Enerji Kimlik Belgesi alınmıştır. Yenilenebilir enerji kullanımları ve bu kullanımlara farkındalık yaratmak amacıyla güneş enerjisinden elektrik üretmeye, yenilenebilir enerji sistemlerini geliştirmeye, mimari yapıların dış mekan ve dekoratif aydınlatmalarına yönelik faaliyetlerde yürütülmeye devam edilmektedir (İBB, 2018).

İstanbul Su ve Kanalizasyon İdaresi (İSKİ) 2016-2020 Stratejik Planı'na göre Güneş Enerjisi Projeleri kapsamında hem sürdürülebilir bir çevre yaratmak hem de var olan kaynakları etkin kullanmak için güneş enerjisinden elektrik elde ederek ihtiyacı olan enerjinin üretilmesinin gerçekleştirilmeyi amaçlanmaktadır. Bu doğrultuda örnek olarak İSKİ verilerine (2018) göre, 2018 yılında yapımı tamamlanan İkitelli Fatih Sultan Mehmet Han Tesisleri'nin elektrik tüketiminin \%8'i olan 1,6 milyon kWh/y1l enerji üretebilen fotovoltaik paneller, İkitelli Fatih Sultan Mehmet Han Tesisi su depolarının üzerinde uygulanmıştır (İSKİ, 2018).

Türkiye dahil çoğu ülkede fotovoltaik panellerin kullanımlarına yönelik stratejik planlar vardır. Karayipler Yenilenebilir Enerji ve Enerji Verimliliği Merkezi 2018 yılının ortasına kadar fotovoltaik panellerinin kullanımı için faaliyete geçmeye yönelik çalışmalar hedeflenmiştir. Karayipler 2030 yilına kadar \% 30'u yerel kurumlar olmak üzere \%50 oranında yenilenebilir enerjiye ulaşmayı hedeflediğini, hükümet binalarına güneş panelleri kurarak dünya liderlerinin yeşil liderler olmalarına yardımcı olmayı amaçlamıştır (URL8). Pakistan'ın hükümet yetkilileri, 2020 yılı ağustos ayından itibaren hedeflerinin yenilenebilir kaynaklardan gelen elektrik gücünün payını yaklaşık \%4'ten 2030'a kadar \%30'a çıkarma planını harekete geçirdiklerini belirtmiştir. Pakistan'ın elektrik karışımının kurulu kapasitesindeki yenilenebilir enerjinin 2025 yılına kadar \%20 ve 2030'a kadar \%30'luk bir payı olacağı ve bu yenilenebilir kaynaklardan ağırlıklı olarak rüzgar ve güneş enerjisinin kullanılması ve bunların yanı sıra jeotermal, gelgit, dalga ve biyokütle enerjisini de içereceği belirtilmiştir (URL 9).

Planlama açısından en iyi ülke olan Fransa'da ise Fransa Hükümeti, 2015 yılında Paris Antlaşması'na da ev sahipliği yapacağı dönemde, ilk ulusal yenilenebilir enerji ve enerji dönüşümü yasasını çıkartmıştır. 2015 yılı Ağustos ayında yürürlüğe giren Yeşil Büyüme için Enerji Dönüşümü Yasası ile 2030 yılında yeşil ekonomik büyüme için enerji dönüşümüne dair enerji politikalarının çerçevesi ortaya konulmuştur. Bu yasanın 5 ana aksiyon prensibi ise;

- Binalarda enerji verimliliğinin ve düşük enerji kullanımını, talep-odaklı enerji yönetimini ve tüketici entegrasyonunu sağlanmak; 
- Vatandaşlar, şirketler ve yerel otoritelerin işbirliğini sağlamak;

- Enerji maliyet ve fiyatlarında şeffaflığı güvence altına almak,

- Enerji alanında çalışma ve araştırmalar yürütmek,

- $\quad$ Enerji karmasını çeşitlendirmek, fosil yakıtların payını azaltmak, elektrik üretiminde kaynak çeşitliliğini arttırmak ve yenilenebilir enerjinin payını arttırmak olarak sıralanabilir (URL7).

Bu yasaya göre enerji tüketimi ve iklim değişiklikleri konusunda 2030 yılına kadar, sera gazı emisyonlarının \%40 azaltılması, yenilenebilir enerjinin kullanılmasında toplam enerji tüketimindeki payının \%32'ye çıkartılması ve tükenen kaynaklardan olan fosil yakıt tüketiminin \%30 azaltılması hedeflenmiştir (OECD, 2016).

Uygulama alanında en iyi ülke olan Almanya bu stratejiye göre 2022 yılı sonuna kadar nükleer enerjinin tamamen bitirilmesi, 2050 yılında ise enerji sisteminin büyük ölçüde yenilenebilir kaynaklara bağlı hale gelmesi hedeflenmektedir. Literatür taraması ile Almanya'da yapılan çalışmalar incelenmiştir. Almanya'daki bu çalışmalarda yenilenebilir enerji kaynaklarına yönelen kullanımların artmasında, yerel yönetimlerin önemli bir yer olduğunu belirtilmiştir (Klagge ve Meister, 2018).

Türkiye' de yerel yönetimler Almanya' da olduğu kadar aktif olmasa da yenilenebilir enerji konusunda halihazırda eylem planları bulunmaktadır. 2014 yılında Avrupa Komisyonu Başkanlar Sözleşmesi sürdürülebilir enerji politikalarını destekleyerek Türkiye'den de 2 büyükşehir belediyesi ve 6 ilçe belediyesi taraf olmuştur. Bu belediyeler; İzmir Büyükşehir Belediyesi, Gaziantep Büyükşehir Belediyesi, İzmir//Bornova, İzmir/Seferihisar, Eskişehir/Tepebaşı, İstanbul/Kadıköy, Bursa/Nilüfer ve Ankara/Çankaya İlçe Belediyesi'dir. Bu sözleşmeye göre bu belediyeler 2020 yılında sera gazı salımlarını ortalama \%20 azaltarak "Sürdürülebilir Enerji Eylem Planlarını" Avrupa Birliğine sunmayı taahhüt etmişlerdir (Bilgiç ve Acet, 2019).

Bu kapsamda yerel yönetim olarak belediyelerin, hükümet binaları ve kamu binalarında kurumsal çevre sorumluluğuna olan katkısı ve her yıl düzenledikleri stratejik hedefleri bulunmaktadır. Bu stratejik hedefler sayesinde karbon salımının azaltılması ve ekolojik çevreye zarar vermeyen uygulamalara yönelim başlamıştır. Bu hedefler doğrultusunda fotovoltaik paneller en verimli yenilenebilir enerji kullanımlarından birisidir.

$\mathrm{Bu}$ çalışma ile fotovoltaik panellerin yurtiçi ve yurtdışında kullanım ve uygulama örnekleri incelenmiştir. Literatür taraması yapılarak daha önce Kurumsal çevre sorumluluğuna yönelik çalışmalar yapan yerel yönetimlerden 8 örnek bir araya getirilmiştir. Özellikle Türkiye'de son 3 yılda uygulamaların baz alınarak güncel olarak uygulanan yapıların incelenmesi ile Türkiye'de de stratejik hedeflerinin son durumuna yönelik çalışmaları ortaya koymak amaçlanmaktadır. İklim, bina formu üzerinde konumu ve elektrik üretimlerine dair karşılaştırmalar yapılan yerel yönetim binalarının binaya entegre veya strüktürel yönden uygulamaları anlatılmaktadır.

Dünya üzerinde özellikle Almanya'nın fotovoltaik kullanımlarında diğer ülkelere göre öncü olması yeni yapılan binalarda olduğu kadar tarihi yapılara uygulamalarında da örnek teşkil etmektedir. Tablo 1'de yer alan Reichstag Alman Parlamento Binası Berlin'de 1894 yılında Birleşik Almanya Meclisi olarak yapılan neoklasik bir yapıdır. Ayrıca binada yakıt gereksinimi de tamamen yenilenebilir enerji kaynaklarından sağlanmaktadır. Almanya'dan başka bir örnek ise cephede kullanım örneğidir. Fotovoltaik paneller Freiburg Teknik İşler Binası cephesinde 880 adet kullanılmıştır. Bu bina net sıfır enerji standardına ulaşarak Almanya'da bunu yapan ilk şehir içi yönetim binası özelliği taşımaktadır.

Tablo 1. Yurtiçi ve yurtdışı fotovoltaik panel kullanımı olan kamu binaları

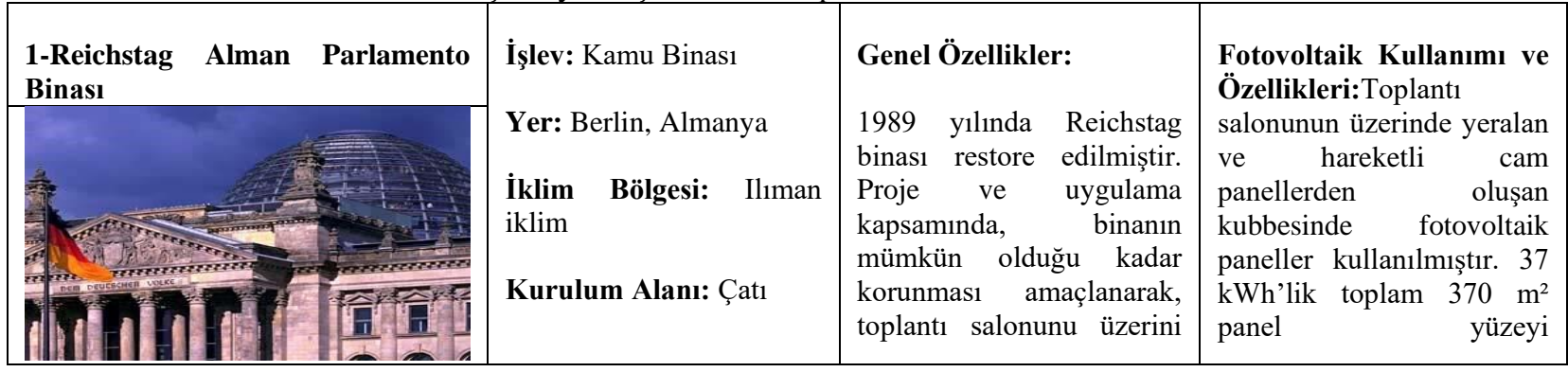




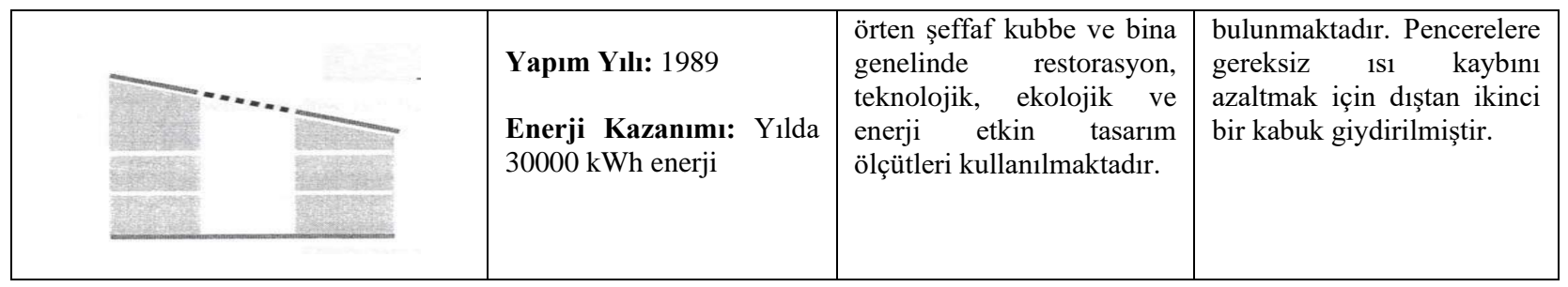

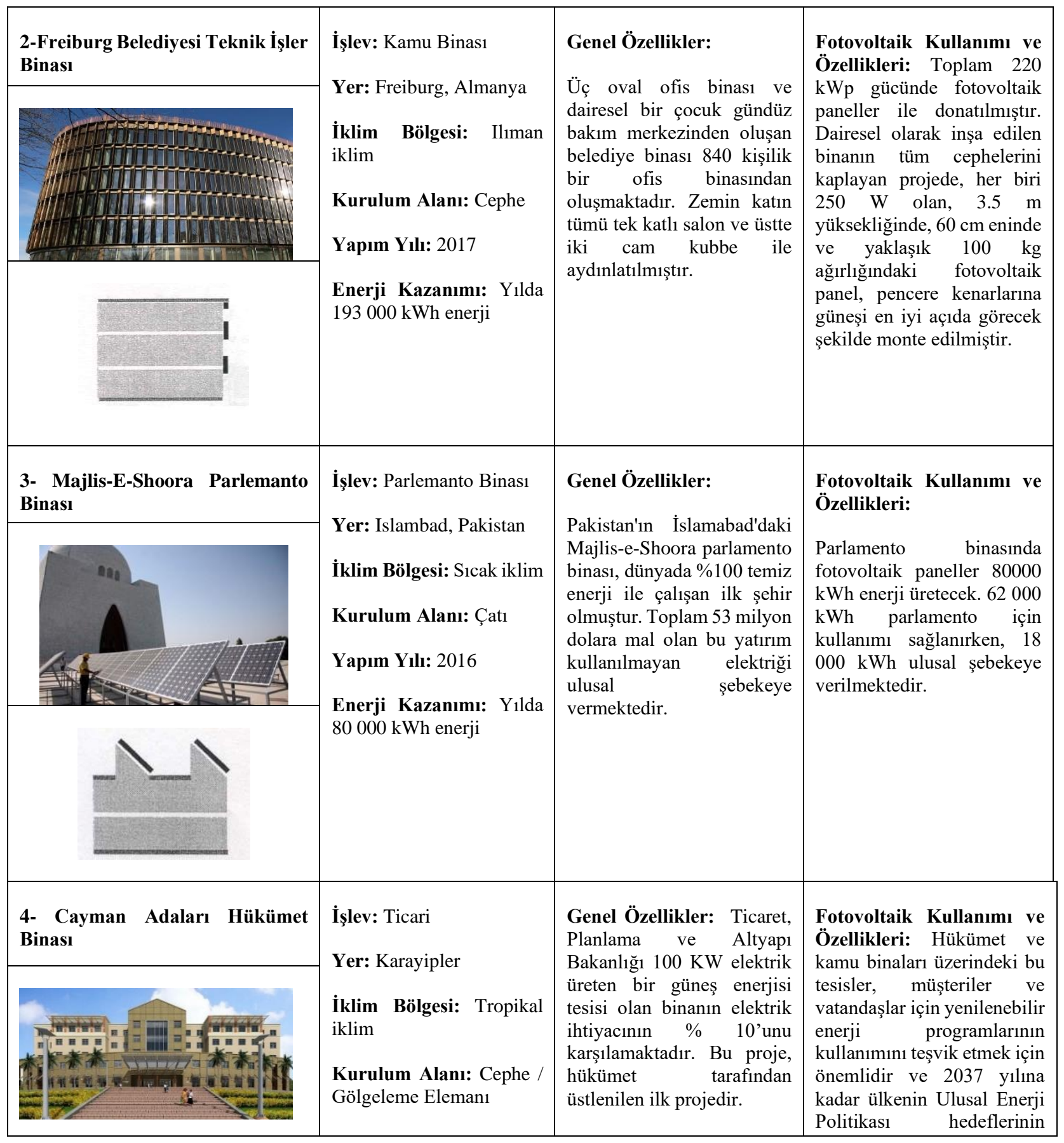




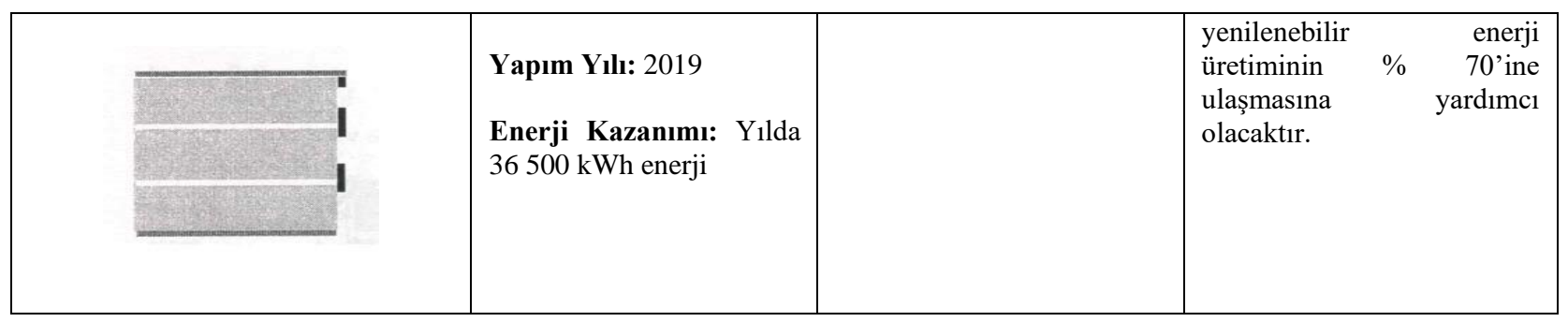

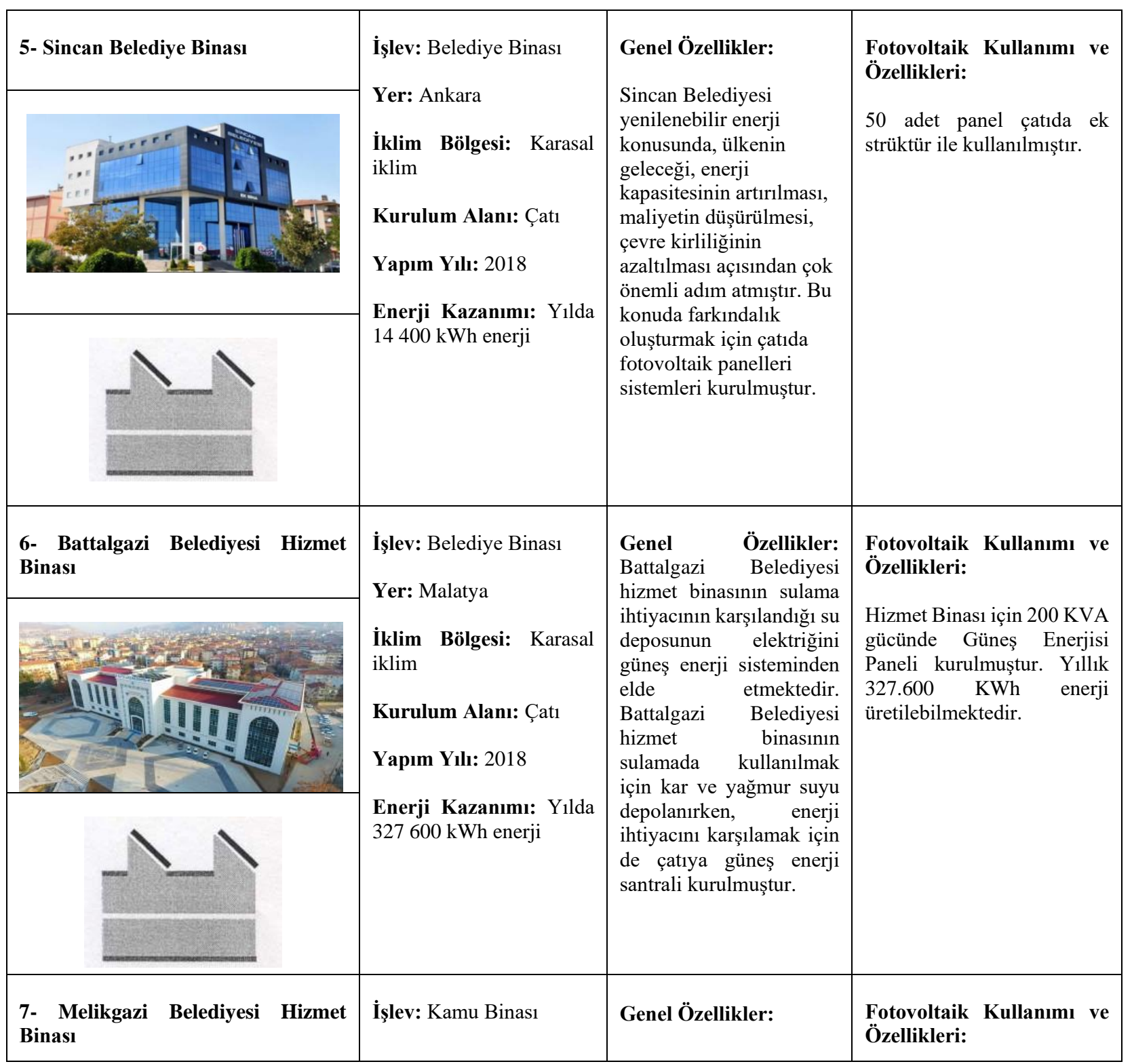




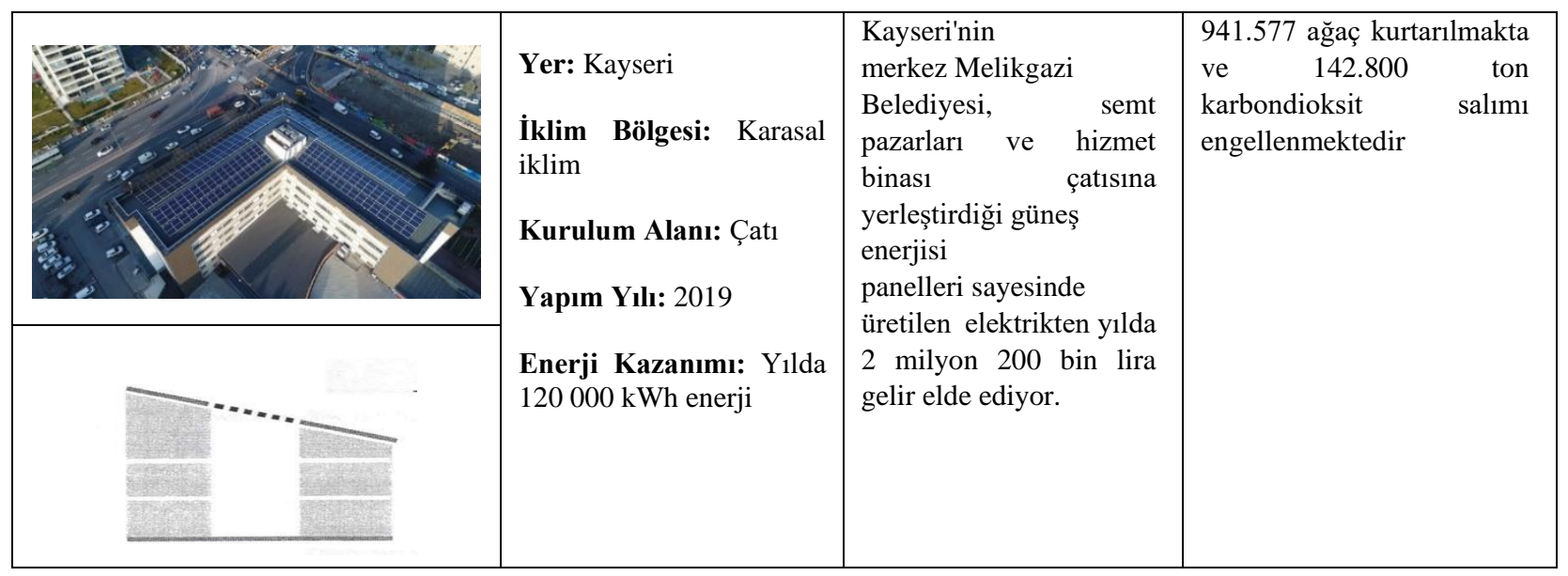

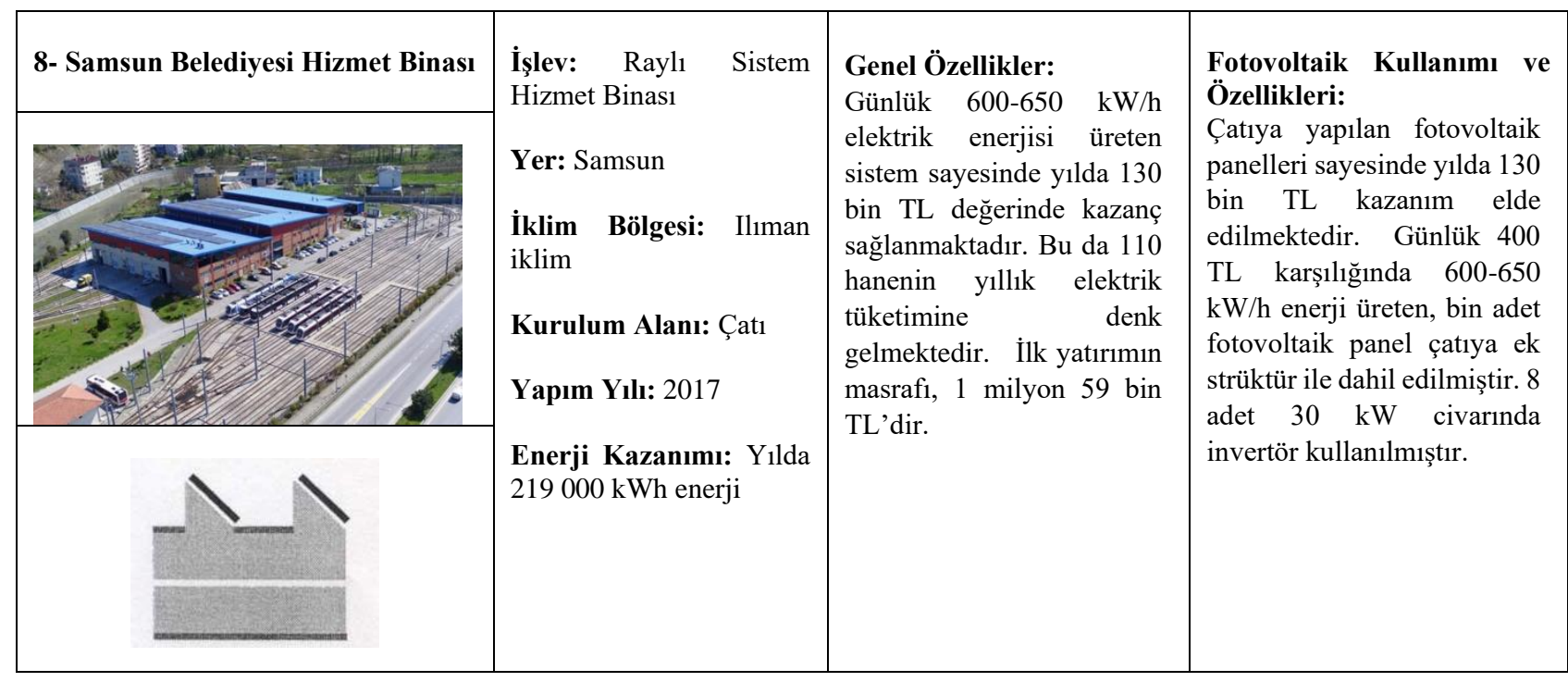

Mevcut yapı üzerinde fotovoltaik panel kullanıma örnek Tablo 1'de bulunan Pakistan parlamentosu dünyada tamamen güneş enerjisi ile çalışan ilk parlamento binasıdır. Fotovoltaik sistemin çatılara ek strüktür ile kurulumu sayesinde Pakistan Hükümeti elektrik maliyetlerinden yılda yaklaşık 1 milyon dolar tasarruf etmesi beklenmektedir. Tasarlanırken planlamaya fotovoltaik panellerinin de dahil edilmesine örnek olarak Karayipler'de bulunan Cayman Adaları Hükümet Binası örnek gösterilebilir. 2019 yılında yapılan ve kullanımına yeni başlanan binanın Tablo 1'de gösterildiği üzere cephede gölgeleme elemanı olarak kullanılması ve gelecek senelerde çatıya ek strüktür yardımıyla güneş panelleri eklemelerine devam edilmesi planlanmıştır. Bununla birlikte 2020 yılından sonra planlanan tüm projelerde, belediye salonlarında, sivil merkezlerde ve diğer hükümet binalarında fotovoltaik panel altyapısı kurulumları planlanmaktadır.

Türkiye'de yapımı tamamlanmış örneklerden ise belediye binalarında en fazla çatıda uygulanmış örnekler bulunmaktadır. Tablo 1'de detayları belirtilen Ankara'da bulunan Sincan Belediye Binas1 yapımı 2018 y1lında tamamlanmıştır. Bu binada düz teras çatı üzerine ek strüktür ile 50 adet fotovoltaik panel yerleştirilmiştir. Türkiye'den diğer örnek 45 dönümlük arazi üzerine kurulan Battalgazi Belediyesi Hizmet Binasıdır. Bina enerji ihtiyacını karşılamak için çatının her alanına eklenen fotovoltaik paneller ile yıllık 327 bin $600 \mathrm{kWh}$ enerji üretmekte ve bu sayede de yıllık yaklaşık 840 ton karbondioksit salımı önlenmesine yardımcı olmaktadır. Kayseri Melikgazi Belediyesi çatısında kullanım ile yılda $120000 \mathrm{kWh}$ enerji sağlamaktadır. Son örnek olan Samsun Büyükşehir Belediyesi, 2 bin 400 metrekare çatısı bulunan Raylı Sistem Hizmet Binasının çatısının bin 600 metrekareli alanına 1000 adet fotovoltaik panel yerleştirilmiştir. 1000 adet fotovoltaik panelin dağıtım şebekesinde kullanılabilecek elektriğe dönüştüren 8 adet 
30 kW civarında invertör bulunmaktadır. Tesisin yıllık kazancı ile birlikte 7 yılda kendisini amorti edecektir. Tablo 1 'de belirtildiği gibi yılda $219000 \mathrm{kWh}$ enerji kazanmaktadır.

\section{Bulgular}

Bu çalışmada yurt içi ve yurt dışı olmak üzere toplam 8 bina incelenmiştir. Bu incelemede şu bulgulara ulaşılmıştır:

- $\quad \mathrm{Bu}$ binaların fotovoltaik panellerin kurulum alanları çatı ve cephe olarak ayrılmıştır. Bina ile entegre sistem veya strüktür sistem olarak binalara farklı uygulamaları bulunmaktadır.

- Incelenen binalar kapsamında genel değerlendirilmesi yapıldığında, enerji kullanımına ilişkin kaygıların tüm binalarda öne çıktığı görülmektedir. Minimum enerji tüketimi ile maksimum enerji kazancı sağlama düşüncesi bina kabuğunda kullanılan fotovoltaik paneller ile sağlanmaktadır. Ancak yurtdışında daha fazla panel kullanımı ile daha fazla elektrik üretimi sağlayabildiği görülmektedir. En eski kullanım ise 1989 yılında Reichstag Alman Parlamento Binasıdır. Türkiye'de ise kullanımlar son 3 yılda başlamıştır.

- Yenilenebilir enerji kaynağı olan güneş enerjisi kullanımı yoluyla çevreye verilen zararı en aza indirme önemlidir. Özellikle karbondioksit salımının azaltılması yönünde Malatya Battalgazi Belediyesi çalışmaları oldukça önemlidir. $3373 \mathrm{~m} 2$ alan kaplayan fotovoltaik paneller sayesinde $327600 \mathrm{kWh}$ elektrik üretimi yaparak ve çevreye duyarlılığını göstermektedir. Malatya Yerel Yönetimi İl genelinde bu tür uygulamaları yaygınlaştırmaya devam etmekte ve farklı işlevde binalarda da kurulumlarının tamamlanmasını hedeflemişlerdir. Kurumsal çevre sorumluluğuna farkındalığı ortaya çıkarması yönünden belediyelerin katkısı büyüktür.

- Bina formu, enerji sağlamayı arttırıcı yönde önemli bir etkendir. Ele alınan örneklerdeki bina formlarıyla direkt güneş ışınımı etkisinde kalan yüzey maksimuma çıkarılmıştır. Diğer taraftan strüktür yardımı ile eğim verilmiş olan mevcut binalarda direkt güneş ışınımını daha fazla alabilmesi için bazı estetik sorunlar ortaya çıkmıştır. Ancak bu uygulamaların hepsinin de çatıda olması nedeniyle görsel açıdan rahatsızlık vermemektedir. Freiburg Belediyesi ve Cayman Adaları Hükümet Binaları bina formuna entegre edilen ve tasarım aşamasında uygulamalarının yapılması nedeniyle estetik olarak bina kabuğuna uyum sağlamaktadır.

Tablo 2. Yerel yönetimlerin yurtiçi ve yurtdışı verilerinin karşılaştırılması

\begin{tabular}{|c|c|c|c|c|c|c|c|}
\hline No & Yerel Yönetimler & Konum & İklim & Yıl & $\begin{array}{c}\text { PV } \\
\text { kapladığı } \\
\text { alan }\end{array}$ & Kurulum Alanı & $\begin{array}{c}\text { Yıllık } \\
\text { Kazanımı }\end{array}$ \\
\hline 1 & $\begin{array}{c}\text { Reichstag Alman } \\
\text { Parlamento Binas1 }\end{array}$ & Almanya & Ilıman & 1989 & $370 \mathrm{~m} 2$ & Çatıya entegre & $30000 \mathrm{kWh}$ \\
\hline 2 & $\begin{array}{c}\text { Freiburg Belediyesi } \\
\text { Teknik İşler Binas1 }\end{array}$ & Almanya & Ilıman & 2017 & $1760 \mathrm{~m} 2$ & Cepheye entegre & $193000 \mathrm{kWh}$ \\
\hline $\begin{array}{c}\text { Majlis-E-Shoora } \\
\text { Parlemanto Binas1 }\end{array}$ & Pakistan & Sıcak & 2016 & $472 \mathrm{~m} 2$ & Çatı strüktürü & $80000 \mathrm{kWh}$ \\
\hline 4 & $\begin{array}{c}\text { Cayman Adaları } \\
\text { Hükümet Binas1 }\end{array}$ & Karayipler & Tropikal & 2019 & $215 \mathrm{~m} 2$ & $\begin{array}{c}\text { Cepheye entegre } \\
\text { gölgeleme elemanı }\end{array}$ & $36500 \mathrm{kWh}$ \\
\hline 5 & $\begin{array}{c}\text { Sincan Belediye } \\
\text { Binası }\end{array}$ & Ankara & Karasal & 2018 & $85 \mathrm{~m} 2$ & Çatı strüktürü & $14400 \mathrm{kWh}$ \\
\hline
\end{tabular}




\begin{tabular}{|c|c|c|c|c|c|c|c|}
\hline 6 & $\begin{array}{c}\text { Battalgazi } \\
\text { Belediyesi Hizmet } \\
\text { Binas1 }\end{array}$ & Malatya & Karasal & 2018 & $3373 \mathrm{~m} 2$ & Çatı strüktürü & $327600 \mathrm{kWh}$ \\
\hline 7 & $\begin{array}{c}\text { Melikgazi } \\
\text { Belediyesi Hizmet } \\
\text { Binası }\end{array}$ & Kayseri & Karasal & 2019 & $704 \mathrm{~m} 2$ & Çatıya entegre & $120000 \mathrm{kWh}$ \\
\hline 8 & $\begin{array}{c}\text { Samsun Büyükşehir } \\
\text { Belediyesi }\end{array}$ & Samsun & Ilıman & 2017 & $1800 \mathrm{~m} 2$ & Çatı strüktürü & $219000 \mathrm{kWh}$ \\
\hline
\end{tabular}

- Tablo 2'ye bakıldığında Almanya'da bulunan Reichstag Alman Parlamento Binası 370 m2'lik yüzey alanına sahip fotovoltaik paneller yıllık $30000 \mathrm{kWh}$ enerji kazanımı sağlamaktadır. Aynı şekilde Pakistan Majlis-EShoora Parlemanto Binası'na bakıldığında $470 \mathrm{~m} 2$ çatıda alan kaplayan fotovoltaik panellerden yıllık enerji kazanımı $80000 \mathrm{kWh}$ olduğu görülmektedir.

Tablo 3. Almanya ve Pakistan Direkt Güneş Işınımı Değerleri

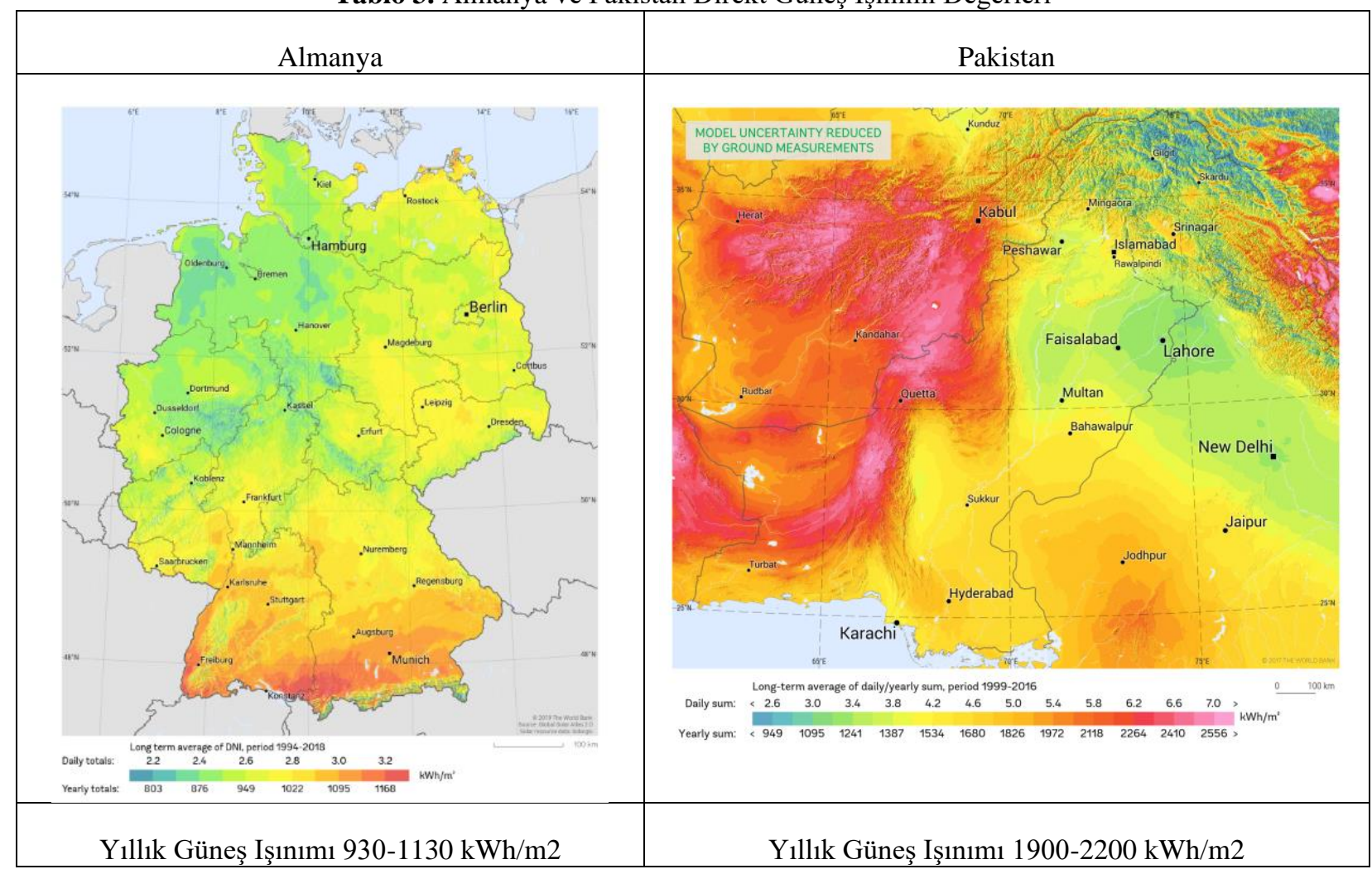

Almanya ve Pakistan karşılaştırıldığında yaklaşık yer kaplanan m2 alanın yakın olmasına rağmen üretilen elektrik miktarı farklıdır. Tablo 3'da görüldüğü gibi bunun sebebi güneş 1şınımlarının iki ülkede farklı olması ve çatıdaki bina formuna olan konumu etki etmektedir. Almanya'da güneş 1şınım şiddeti $930-1130$ $\mathrm{kWh} / \mathrm{m} 2$ 'dir. Pakistan güneş 1şınımı şiddeti $1900-2200 \mathrm{kWh} / \mathrm{m} 2$ 'dir. Bu aradaki fark fotovoltaik panellerindeki elektrik üretim verimin değiştirmektedir. Güneş ışınımlarının fotovoltaik panellerine dik bir şekilde ulaşması elektrik üretimini arttıracaktır. Almanya'daki binaya bakılacak olursa, çatının kubbe şeklinde bina formu olması Almanya'da daha az olan güneş ışınımının yanı sıra eğimin güneşe göre daha az dik açı ile ulaşabilmesini zorlaştırılmasından dolayı $370 \mathrm{~m} 2$ panel kullanılmasına rağmen daha az elektrik üretimi yapıldığg görülmektedir. 


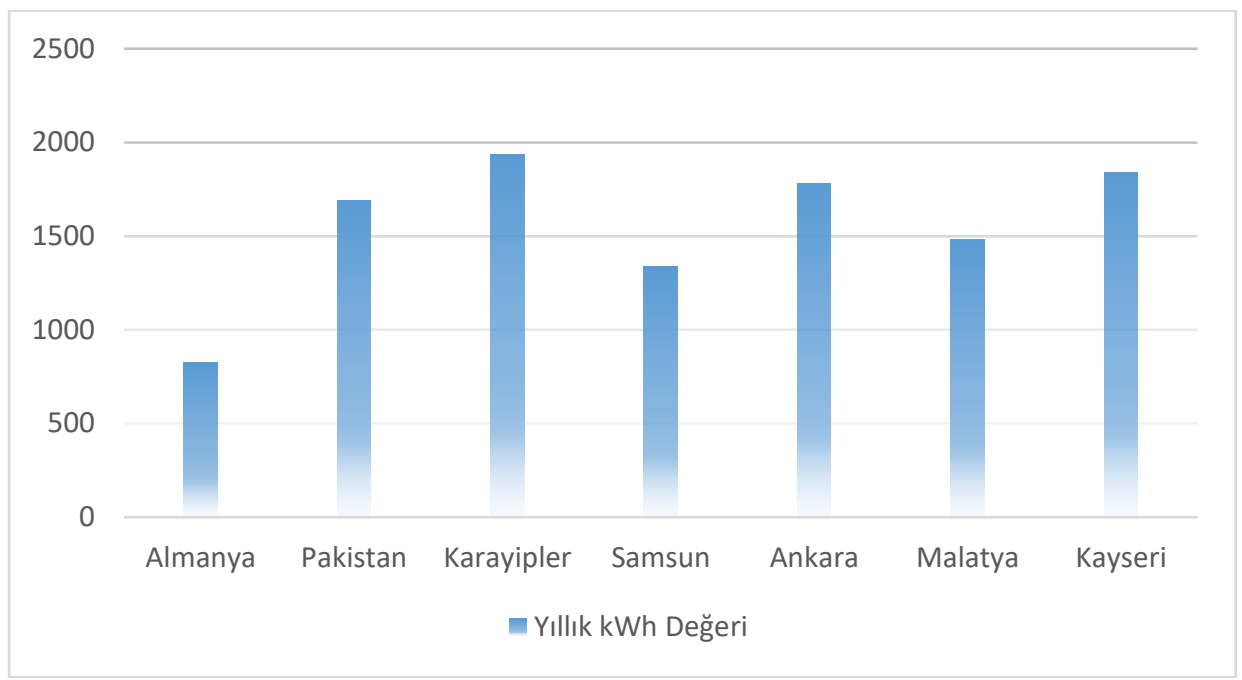

Şekil 1. Yıllık direkt güneş 1şınımı ülkelerin metrekare başına kWh değeri

- Şekil 1'de güneş ışınımlarının yıllık kWh değerini gösteren grafik yer almaktadır. Bu grafikte en fazla güneş 1şınımını alan fotovoltaik panellerinde elektrik üretimi en fazla üretim yapmaktadır. Bu faktör de bina formuna uygulandığı durumda daha az panel ile daha fazla elektrik üretimi sağlanmış olur. Güneş ışınımlarını en fazla alan ülke ve iller sıralaması şu şekildedir; en fazla Karayipler (Cayman Adası), Kayseri, Ankara, Pakistan (Islamabad), Malatya, Samsun ve en az güneş ışınımı Almanya (Freiburg ve Berlin)'dir.

- İklim koşulları, nem, aşırı sıcaklara karşı panelin havalandırılması ve panellerin bina üzerindeki konumları elektrik üretim kazancına etki eden faktörlerdir. İncelenen projelerin tamamında bölgenin iklimsel özellikleri dikkate alınarak geliştirilen tasarımlar söz konusudur. Binanın güneş alma saatlerine göre PV yüzey alanı belirlenmekte ve yönelme tüm yapılarda önem kazanmaktadır. Özellikle ılıman iklim kuş̧ă̆ olan bölgelerde elektrik üretim verim fazla olmaktadır. Nem ve sıcak hava fotovoltaik panellerinin çalışmasını olumsuz etkilemektedir. Sıcak hava panellerde aşırı ısınma yaratarak elektrik üretimini verimini düşürmektedir. Nemli bölgeler ise güneş ışınlarının panellere dik şekilde ulaşmasını engelleyen su damlaları oluşturmasından dolayı elektrik üretimi verimini düşürmektedir (Karaca ve Uçar, 2018).

\section{SONUÇ VE ÖNERILER}

Türkiye avantajlı konumu ile yıllık güneşlenme süresi ve güneş ışınım şiddeti, birçok Avrupa ülkesinden fazladır. Bu avantajı yenilenebilir enerjilerden olan güneş enerjisi ile kullanılarak geliştirilen devlet destekli projelerle, farkındalığın oluşturulması ile mimarları enerji etkin binalar tasarlamaya yönlendirmek, ülkemizi de enerji ihtiyacı bakımından dışa bağımlı ülke olma konumundan kurtaracaktır. Çoğu belediyede bina üzerinde kullanımlar yeni başlasa bile, ülkemizde arazilere kurulan GES sistemlerinin daha fazla yaygınlaştığı görülmektedir. Son 3 yılda belediyeler binalarına da fotovoltaik panellerin eklemesiyle kurumsal çevre sorumluluğunu stratejik plan olarak hedeflerine almaktadırlar. İstanbul Belediyesi'nin de 2020/2021 yılında başlayacağı İSKİ binalarının tamamının cephe ve çatısında fotovoltaik panel eklenerek cephede de kullanımı olan Türkiye'de ilk belediye olacaktır.

Türkiye'de yeni kavram olan Kurumsal Çevre Sorumluluğu, Kurumsal Sosyal Sorumluluğun bir parçasıdır. Çoğu ülke, sürdürülebilir kalkınma planları kapsamında yer alan sürdürülebilir enerji politikalarıyla birlikte çevreye olan duyarlılı̆ııı sağlanması ve ekolojik dengenin binalar tarafından bozulmasını engelleyecek önlemler almaktadır. Böylece kurumlarda yaşam standardını yükselterek, ekolojiye zarar vermeyen yeni yöntemler ile teknolojinin de kullanım olanakları sağlanmaktadır. Buna bağlı olarak Kurumsal Çevre Sorumluluğu için stratejik hedefler belirlemişlerdir. Bu hedefler karşılı̆̆ında, bulundukları kurumun çevreye katkısı özellikle yerel yönetim binalarında uygulaması önemlidir. Yenilenebilir enerji kaynaklarından her ülkenin güneşten yararlanılabilmesi ve güneş enerjisini elektrik enerjisine dönüştüren fotovoltaik panellerin kullanımlarının önemini arttırdığı görülmektedir. 
Bu çalışma ile 8 farklı yerel yönetim binaları incelenmiştir. Bu binalar iklim, m2, bina formuna entegresi ve yıllık enerji kazanımları yönünden karşılaştırılmıştır. Bu incelenen yapıların 3 farklı şekilde bina formuna fotovoltaik paneller dahil edilerek kullanılmıştır. Bunlar; çatılar, cepheler ve cephede gölgeleme elemanı olarak kullanılmasıdır. Binanın coğrafi konumunun elektrik üretimine etkisi olduğu görülmektedir. Tablo 2'de binaların farklı iklimsel bölgede olması güneşi en fazla şekilde alabilen ülkede daha verimli elektrik üretimi sağlayacağını göstermiştir. Yapı üzerinde en fazla güneş alabilen alanlar çatılardır. Çatıların olması ve güneşı ı̧ınlarını dik alabilmek için ek strüktür yardımıyla iklim ve bölgeye göre rahatlıkla eğim verilen alanlar olması sebebiyle, binalarda kullanımlar çatıda daha yoğun kullanıldığı incelenmiştir.

Fotovoltaik panellerin binalarda uygulamaları ile hem elektrik gereksinimi karşılanırken hem de çevre bilincinin arttırılması hedeflenmektedir. Türkiye avantajlı konumu ile bu avantajı değerlendirip güneş enerjisinden yararlanarak binalarda kullanımlarının yaygınlaşması, kamuoyu bilinçlendirilerek mimarların fiziksel çevreyle birlikte enerji etkin binalar tasarlamaya yönlendirerek, enerji ihtiyacının dış ülkelerden karşılanmasını azaltmak ve en sonunda da engellemek gerekmektedir. Örnek verilen kamu binalarının da halk ile iç içe binalar olması sebebiyle, kullanım alanlarını görebilecekleri ve bilinçlenebilecekleri ortam sağlamaktadır. Son yıllarda yaşanan çevre sorunlarının sonucu olarak, tüm sektörlerde ekolojik yaklaşımlar önem kazanmıştır. Ekosisteme verilen zararlar konusunda, çevre hakkında bilinçlenme, tüm dünya üzerinde artmaya devam etmektedir. Dünya üzerinde de en fazla enerji tüketimi binalar tarafından gerçekleşmesi de yenilenebilir enerji kaynaklarını binalara entegre ederek çevreye verilen zararı azaltmaya yardımcı olacaktır. Kurumsal çevre sorumluluğun sadece yerel yönetimler ile sınırlı kalmaması ile tüm kurumlara bu kavramın yaygınlaştırılması binalara çevresel etkilere yönelik tasarımlar yapılmasında etkili olacaktır.

\section{Etik Standart ile Uyumluluk}

Çıkar Çatışması: Yazarlar herhangi bir çıkar çatışmasının olmadığını beyan eder.

Etik Kurul İzni: Bu çalışma için etik kurul iznine gerek yoktur.

Finansal Destek: Yoktur

Teşekkür:

\section{KAYNAKÇA}

AKKOYUNLU, G. Ş., ve KALYONCUOĞLU, S. (2014). İşletmelerin Kurumsal Sosyal Sorumluluk Çalışmalarının Marka Algısı Üzerine Etkisinin Değerlendirilmesi. Niğde Üniversitesi İ̈BF Dergisi, 7(3), 125-144.

ARSLAN, H. H. P. ve, AKŞİT, Ş. F. (2016). Energy efficient mobile building design. ITU J Faculty Arch. ; 13(2): 4756

BİLGİÇ, A. K. ve ACET, D. B. (2019). Yerel Yönetim Politikalarında Yenilenebilir Enerji. Kent Araştırmaları Dergisi. 27 (10). 410-446.

GROVER, S. (2007). Energy, Economic, and Environmental Benefits of the Solar America Initiative No. ADJ-777253-01

HU, A., LEVIS, S. ve diğerleri (2015) Impact of solar panels on global climate. Nature Climate Change, 6, 290-294.

İstanbul Büyükşehir Belediyesi Faaliyet Raporu (2018).

İSKİ Faaliyet Raporu ( 2018).

KLAGGE, B., ve MEÍSTER, T. (2018). Energy cooperatives in Germany-an example of successful alternative economies?. Local Environment, 23(7), 697-716. 
KARACA, Ü. B. ve UÇAR, S. (2018). Konut çatı ve cephelerinde farklı fotovoltaik sistem uygulamalarının değerlendirilmesi. Trakya Üniversitesi Mühendislik Bilimleri Dergisi, 19(2), 65-76.

MERT, Y. L. (2018). Belediyelerde Kurumsal Sosyal Sorumluluk Uygulamaları: İ́stanbul Büyükşehir Belediyesi Örneği. Uluslararası Sosyal Araştırmalar Dergisi, 11, 923-936.

Organisation for Economic Co-operation and Development [OECD]. (2016, Ekim). OECD environmental performance reviews: France 2016. Paris: OECD Publishing

PELITT, E., KELEŞ, Y. ve ÇAKIR, M. (2009). Otel İşletmelerinde Sosyal Sorumluluk Uygulamalarının Belirlenmesine Yönelik bir Araştırma. Yönetim ve Ekonomi Dergisi, Cilt:16(2), s.19-30.

SAĞLAM, N. G. ve YILMAZ, A. Z. (2015). Avrupa Birliği Direktifi Doğrultusunda Binalarda Yaklaşık Sıfır Enerji Düzeyinin Akdeniz Ülkesi Olan Türkiye'de Konut Binaları İçin Belirlenmesine Yönelik Uygulama Örneği. Tesisat Mühendisliği, 148, 82-96.

VAN STADEN, M. (2017). Sustainable energy transition: Local governments as key actors. (T. S. Uyar, Der.) Towards $100 \%$ Renewable Energy s.17 - 25. Springer,

World Nuclear Performance Report (WNA Report), 2019

URL 1 : http://www.enerji-dunyasi.com/yayin/258/dunya-enerji-sisteminde-dort-onemli-degisim-yasaniyor_7894.

html \#.Xo2E7DfVKUk, Son Erişim Tarihi: 08/04/2020

URL 2 : www.tdk.gov.tr, Son Erişim Tarihi: 08/04/2020

URL 3 : https://www.sciencedaily.com/releases/2016/05/160518165257.html, Son Erişim Tarihi: 08/04/2020

URL 4 :https://greentumble.com/what-are-the-environmental-benefits-of-solar-energy/,Son Erişim Tarihi: 08/04/2020

URL 5 : https://population.un.org/wup/Publications/Files/WUP2018-KeyFacts.pdf, Son Erişim Tarihi: 08/04/2020

URL 6 : http://www.irena.org/-/media/Files/IRENA/Agency/Publication/2016/IRENA_Renewable_Energy_in_Cities _2016.pdf, Son Erişim Tarihi: 08/04/2020

URL 7 : https://www.iea.org/ publications/freepublications/publication/Energy_Policies_of_IEA_Countries_France_ 2016_Review.pdf, Son Erişim Tarihi: 11/11/2019

URL 8: https://renewableenergycaribbean.com/2018/10/17/jamaican-pm-reveals-personal-ambition-for-50renewables-by-2030/ Son Erişim Tarihi: 29/09/2020

URL 9: https://ieefa.org/new-pakistani-energy-plan-aims-for-30-renewable-generation-by-2030/ Son Erişim Tarihi: $29 / 09 / 2020$

URL 10: https://webdosya.csb.gov.tr/db/cygm/icerikler/yed-nc--ulusal-b-ld-r-m-20190909092640.pdf Son Erişim Tarihi: 29/09/2020 